\title{
PHENYLGLYOXAL DIHYDRAZONES AS UNEXPECTED PRODUCTS IN THE SYNTHESIS OF 1,2,4-TRIAZINES BY INTERACTION OF $\alpha$-BROMOACETOPHENONES AND ARYLHYDRAZIDES
}

\author{
D. S. Kopchuk ${ }^{1,2, *}$, I. S. Kovalev ${ }^{1}$, G. V. Zyryanov ${ }^{1,2}$, A. F. Khasanov ${ }^{1}$, \\ A. S. Medvedevskikh ${ }^{1}$, V. L. Rusinov ${ }^{1,2}$, and O. N. Chupakhin ${ }^{1,2}$
}

On interacting $\alpha$-bromoacetophenones with aromatic carboxylic acid hydrazides, the formation of two reaction products was observed in certain cases, the expected 1,2,4-triazine and the phenylglyoxal dihydrazone as an unexpected product. The effect of substituents in the initial substrates and of the conditions of carrying out the synthesis on the direction of the reaction have been studied.

Keywords: aromatic acid hydrazides, $\alpha$-bromoacetophenone, phenylglyoxal dihydrazone, 1,2,4-triazine, condensation.

1,2,4-Triazines are of interest as convenient substrates in cycloaddition reactions [1-3]. In addition, they are of interest due to their biological activity [4-6], their use as selective extractants of metal cations [7-10] (such as the actinoids), and as ligands for cations of transition metals [11].

One of the traditional methods of obtaining 3,6-disubstituted 1,2,4-triazines is the interaction of $\alpha$-bromoacetophenones with two equivalents of carboxylic acid hydrazides [12]. We discovered that in a series of cases of this reaction, in addition to the expected 1,2,4-triazines one further product, the phenylglyoxal dihydrazone, was formed.

In particular, on refluxing $\alpha$-bromo-3-nitroacetophenone 1a with hydrazides $\mathbf{2 a}$,b in a EtOH-AcOH, 3:1 mixture under an atmosphere of argon in the presence of sodium acetate, the formation of 1,2,4-triazines 3a,b in $41-45 \%$ yield and of 3-nitrophenylglyoxal dihydrazones $\mathbf{4 a , b}$ in $14-16 \%$ yield was established. An effective method of separating compounds $\mathbf{3 a}, \mathbf{b}$ and $\mathbf{4 a}, \mathbf{b}$ used by us was based on their different solubilities. After carrying out the synthetic procedure, the formation was observed first of precipitates of the less soluble cyclic 1,2,4-triazines 3a,b, and only after extended delay the formation of precipitates of the more soluble hydrazones $\mathbf{4 a}, \mathbf{b}$ did occur. On carrying out the reaction in air, the fraction of dihydrazones $\mathbf{4 a}, \mathbf{b}$ in the reaction products grew significantly (to $40-45 \%$ ), and the yields of 1,2,4-triazines $\mathbf{3 a}, \mathbf{b}$ were reduced to $10-15 \%$.

*To whom correspondence should be addressed, e-mail: dkopchuk@mail.ru.

${ }^{1}$ Ural Federal University named after the First President of Russia B. N. Yeltsin, 19 Mira St., Yekaterinburg 620002, Russia.

${ }^{2}$ I. Ya. Postovskii Institute of Organic Synthesis, Ural Branch of the Russian Academy of Sciences, 22 S. Kovalevskoi St., 20 Akademicheskaya St., Yekaterinburg 620219, Russia; e-mail: chupakhin@ios.uran.ru.

Translated from Khimiya Geterotsiklicheskikh Soedinenii, No. 7, pp. 1060-1064, July, 2013. Original article submitted June 5, 2012; revision submitted December 26, 2012. 


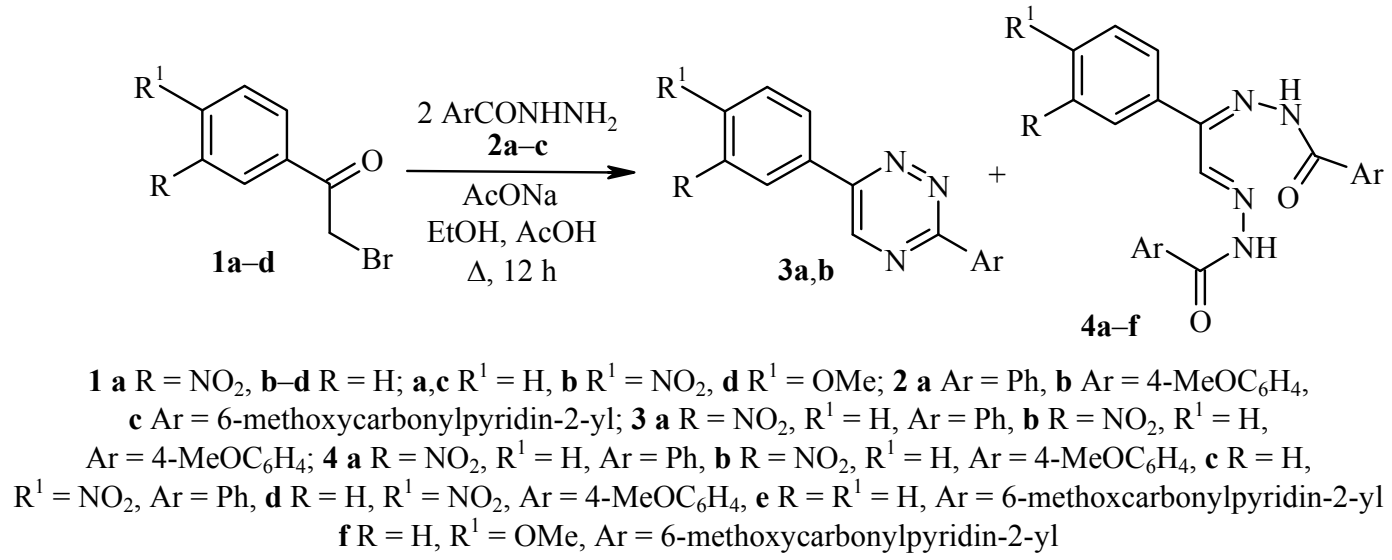

In the case of using $\alpha$-bromo-4-nitroacetophenone $\mathbf{1 b}$, the formation of exclusively 4-nitrophenylglyoxal dihydrazones $\mathbf{4 c}$,d in $36-42 \%$ was observed. The expected 1,2,4-triazines were formed in only trace amounts even on carrying out the reaction under an argon atmosphere.

It was shown previously [13] that on interacting 6-methoxycarbonylpyridine-2-carboxylic acid hydrazide (2c) with $\alpha$-bromo-4-methoxyacetophenone 1d in a $\mathrm{EtOH}-\mathrm{AcOH}, 4: 1$ mixture, the corresponding triazine may be obtained in moderate yield. However, when using a different ratio of solvents $(\mathrm{EtOH}-\mathrm{AcOH}$, 1:3), the sole isolated reaction products were dihydrazones 4e,f. Carrying out the reaction under an argon atmosphere in this case did not lead to any significant change.

It is evident that compounds $\mathbf{4}$ are the products of oxidation of the intermediate compounds $\mathbf{A}$ by oxygen of the air. Compounds $\mathbf{A}$ are formed as a result of alkylation of acid hydrazide $\mathbf{2}$ by bromoacetophenone 1 (alternative reaction route). It should be mentioned that compounds $\mathbf{4}$ may no longer be converted into triazines 3.

Structures similar to compounds $\mathbf{4}$ have previously been described only in the sole publication [14], and the procedure for separation and isolation of the reaction products was more complex than that proposed within the present work.

The structures of the compounds obtained were confirmed by data of IR, ${ }^{1} \mathrm{H}$ and ${ }^{13} \mathrm{C}$ NMR spectra, mass spectroscopy, and elemental analysis. In the NMR spectra, the presence of two fragments of carboxylic acid hydrazide was noted unequivocally. In addition, the one-proton singlet of the azomethine hydrogen atom at 8.65-8.85 ppm and the two broadened singlets for protons of the NH group were characteristic. The IR

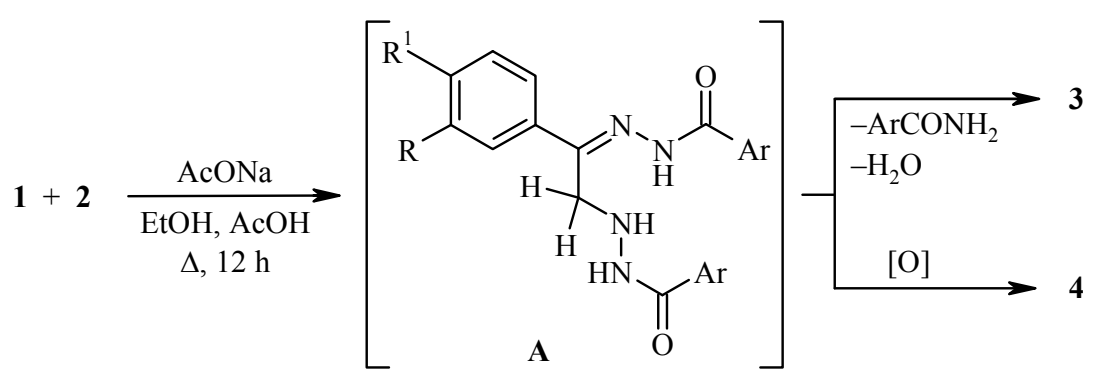

spectra contained bands corresponding to the stretching vibrations of the carbonyl groups, and also to the NH groups. In the ${ }^{13} \mathrm{C}$ NMR spectra, the downfield signals of the carbonyl groups in the $160-165$ ppm region should be mentioned. Signals of the aliphatic methylene group at 4.00-4.50 ppm were absent which enables the product to be assigned the structure 4 but not $\mathbf{A}$. 
In the case of dihydrazones $\mathbf{4 c}, \mathbf{d}$ in the ${ }^{1} \mathrm{H}$ NMR spectra the presence was noted of two signals of the $\mathrm{NH}$ groups, and in the spectrum of compound $\mathbf{4} \mathbf{c}$ two signals were also observed for the azomethine proton (the ratio of the intensities of the signals was close to 1:1). This may be explained by the presence of two geometric isomers (cis and anti) of the given compounds. The ${ }^{13} \mathrm{C}$ NMR spectra contained a larger set of carbon signals than expected if one isomer was present, which also confirms this hypothesis. It should be noted that a such effect was established only for compounds $\mathbf{4 c}, \mathbf{d}$, other dihydrazones showed the presence of only one isomer.

When obtaining 3,6-disubstituted 1,2,4-triazines by the interaction of $\alpha$-bromoacetophenone with two equivalents of carboxylic acid hydrazides it is therefore necessary to take into account the possibility of the formation of noncyclic secondary products - dihydrazones of glyoxal derivatives. The extent of forming these products depends on the nature of the substituents in the starting compounds, a series of particular cases was considered in the present work. Thus, in the case of using $\alpha$-bromo-4-nitroacetophenone, the arylglyoxal dihydrazones are the dominant reaction product, carrying out the interaction under an atmosphere of argon does not introduce significant changes. A different rule was noted on using $\alpha$-bromo-3-nitroacetophenone, in this case on carrying out the reaction under an argon atmosphere the main products were 1,2,4-triazines, the arylglyoxal dihydrazones were formed to a significantly lesser extent. However, carrying out the reaction in the air changes the ratio of products to the opposite, the dihydrazone becomes the main product. Consequently in this case, on account of the change in the nature of the atmosphere it is possible to direct this reaction on the necessary route. On using 6-methoxycarbonylpyridine-2-carboxylic acid hydrazide the key role in directing the reaction is played by the solvent. An increase in the proportion of ethanol directs the reaction along the route of forming the triazine, an increase in the proportion of acetic acid directs along the route of forming dihydrazone.

\section{EXPERIMENTAL}

The IR spectra were recorded on a Bruker Alpha Fourier spectrometer with a NPVO (ZnSe) attachment. The ${ }^{1} \mathrm{H}$ and ${ }^{13} \mathrm{C}$ NMR spectra were recorded on a Bruker DRX-400 spectrometer (400 and $100 \mathrm{MHz}$, respectively) in DMSO- $\mathrm{d}_{6}$, standard was TMS. Mass spectra (ionization by electrospray) were recorded on a MicrOTOF-Q II mass spectrometer (Bruker Daltonics). Elemental analysis was carried out on a Perkin-Elmer PE $2400 \mathrm{CHN}$ analyzer, series II. Melting points were determined on a Boetius hot stage apparatus. TLC was carried out on Merck silica gel 60F254 plates, eluent was EtOAc, visualization in UV light.

Preparation of 1,2,4-Triazines 3a,b and Dihydrazones 4a-d (General Method). A mixture of nitroacetophenone 1a,b $(8.20 \mathrm{mmol})$, carboxylic acid hydrazide 2a,b $(16.40 \mathrm{mmol})$, and $\mathrm{NaOAc}(0.81 \mathrm{~g}$, $9.84 \mathrm{mmol})$ was refluxed with stirring in a $\mathrm{EtOH}-\mathrm{AcOH}, 3: 1$, mixture $(150 \mathrm{ml})$ for $12 \mathrm{~h}$ under an argon atmosphere. The reaction mixture was cooled to room temperature and maintained for $30 \mathrm{~min}$. In the case of $\alpha$-bromo-3-nitroacetophenone 1a, the precipitated solid (1,2,4-triazines 3a,b) was filtered off, washed with $\mathrm{EtOH}$, and dried. The filtrate was stored at room temperature for $12 \mathrm{~h}$, the precipitated solid (dihydrazones $\mathbf{4 a}, \mathbf{b}$ ) was filtered off, washed with EtOH, and dried. An analytical sample was recrystallized from EtOH. In the case of $\alpha$-bromo-4-nitroacetophenone $\mathbf{1 b}$, the formation of solid 1,2,4-triazine did not occur, after maintaining the reaction mixture for $30 \mathrm{~min}$ the solid dihydrazones $\mathbf{4 c}$,d were filtered off, washed with $\mathrm{EtOH}$, and dried.

6-(3-Nitrophenyl)-3-phenyl-1,2,4-triazine (3a). Yield $1.03 \mathrm{~g} \mathrm{(45 \% ),} \mathrm{yellow} \mathrm{crystals,} \mathrm{mp} 226-228^{\circ} \mathrm{C}$. ${ }^{1} \mathrm{H}$ NMR spectrum, $\delta$, ppm $(J, \mathrm{~Hz}): 7.59-7.63(3 \mathrm{H}, \mathrm{m}, \mathrm{H} \mathrm{Ph}) ; 7.91\left(1 \mathrm{H}, \mathrm{dd},{ }^{3} J=8.0,{ }^{3} J=8.0, \mathrm{H}-5 \mathrm{Ar}\right) ; 8.40-8.44(1 \mathrm{H}$, m, H-6 Ar); 8.52-8.56 (2H, m, H Ph); 8.70-8.74 (1H, m, H-4 Ar); $9.11\left(1 \mathrm{H}, \mathrm{dd},{ }^{4} J=2.0,{ }^{4} J=2.0, \mathrm{H}-2 \mathrm{Ar}\right) ; 9.62(1 \mathrm{H}$, s, H-5). Found, \%: C 64.55; H 3.49; N 20.05. $\mathrm{C}_{15} \mathrm{H}_{10} \mathrm{~N}_{4} \mathrm{O}_{2}$. Calculated, \%: C 64.74; H 3.62; N 20.13.

3-(4-Methoxyphenyl)-6-(3-nitrophenyl)-1,2,4-triazine (3b). Yield $1.06 \mathrm{~g}$ (42\%), yellow crystals, $\mathrm{mp}$ 215-217 ${ }^{\circ} \mathrm{C} .{ }^{1} \mathrm{H}$ NMR spectrum, $\delta$, ppm $(J, \mathrm{~Hz}): 3.90\left(3 \mathrm{H}, \mathrm{s}, \mathrm{OCH}_{3}\right) ; 7.06-7.10(2 \mathrm{H}, \mathrm{m}, \mathrm{H}$ ArOMe $) ; 7.88(1 \mathrm{H}$, $\left.\mathrm{dd},{ }^{3} J=8.0,{ }^{3} J=8.0, \mathrm{H}-5 \mathrm{ArNO}_{2}\right) ; 8.37-8.41\left(1 \mathrm{H}, \mathrm{m}, \mathrm{H}-6 \mathrm{ArNO}_{2}\right) ; 8.46-8.50(2 \mathrm{H}, \mathrm{m}, \mathrm{H}$ ArOMe$) ; 8.66-8.70$ $\left(1 \mathrm{H}, \mathrm{m}, \mathrm{H}-4 \mathrm{ArNO}_{2}\right) ; 9.08\left(1 \mathrm{H}, \mathrm{dd},{ }^{4} J=2.0,{ }^{4} \mathrm{~J}=2.0, \mathrm{H}-2 \mathrm{ArNO}_{2}\right) ; 9.49(1 \mathrm{H}, \mathrm{s}, \mathrm{H}-5)$. Found, \%: C 62.21; $\mathrm{H}$ 3.77; $\mathrm{N}$ 17.94. $\mathrm{C}_{16} \mathrm{H}_{12} \mathrm{~N}_{4} \mathrm{O}_{3}$. Calculated, \%: C 62.34; H 3.92; N 18.17 . 
3-Nitrophenylglyoxal Bisbenzoylhydrazone (4a). Yield $0.46 \mathrm{~g}$ (14\%), light-yellow crystals, $\mathrm{mp}$ 246-248 ${ }^{\circ}$ C. IR spectrum, $v, \mathrm{~cm}^{-1}: 1705(\mathrm{CO}), 3061(\mathrm{NH}), 3198(\mathrm{NH}), 3309(\mathrm{NH}) .{ }^{1} \mathrm{H}$ NMR spectrum, $\delta$, ppm $(J, \mathrm{~Hz}): 7.54-7.68(6 \mathrm{H}, \mathrm{m}, \mathrm{H} \mathrm{Ph}) ; 7.80\left(1 \mathrm{H}, \mathrm{dd},{ }^{3} J=8.0,{ }^{3} J=8.0, \mathrm{H}-5 \mathrm{Ar}\right) ; 8.01-8.06$ (2H, m, H Ph); 8.27-8.34 $(2 \mathrm{H}, \mathrm{m}, \mathrm{H}-4,6 \mathrm{Ar}) ; 8.35-8.42(2 \mathrm{H}, \mathrm{m}, \mathrm{H} \mathrm{Ph}) ; 8.60\left(1 \mathrm{H}, \mathrm{dd},{ }^{4} J=2.0,{ }^{4} \mathrm{~J}=2.0, \mathrm{H}-2 \mathrm{Ar}\right) ; 8.84(1 \mathrm{H}, \mathrm{s}, \mathrm{CH}=\mathrm{N})$; $12.42\left(1 \mathrm{H}\right.$, br. s, NH); $14.66\left(1 \mathrm{H}\right.$, br. s, NH). ${ }^{13} \mathrm{C}$ NMR spectrum, $\delta$, ppm: $121.3 ; 124.3 ; 128.3 ; 128.4 ; 128.6$; $129.2 ; 129.4 ; 129.7 ; 130.9 ; 132.6 ; 133.1 ; 133.2 ; 133.3 ; 133.9 ; 138.6 ; 148.5 ; 163.9 ; 164.0$. Mass spectrum, $m / z$ $\left(I_{\text {rel }}, \%\right): 416.13[\mathrm{M}+\mathrm{H}]^{+}$(100). Found, \%: C 63.40; H 4.04; N 16.90. $\mathrm{C}_{22} \mathrm{H}_{17} \mathrm{~N}_{5} \mathrm{O}_{4}$. Calculated, \%: C 63.61; H 4.12; N 16.86 .

3-Nitrophenylglyoxal Bis(4-methoxybenzoyl)hydrazone (4b). Yield $0.60 \mathrm{~g}$ (16\%), light-yellow crystals, mp $158-160^{\circ} \mathrm{C}$. IR spectrum, $v, \mathrm{~cm}^{-1}: 1676(\mathrm{CO}), 3149(\mathrm{NH}), 3406(\mathrm{NH}) .{ }^{1} \mathrm{H}$ NMR spectrum, $\delta$, ppm $(J, \mathrm{~Hz}): 3.89\left(3 \mathrm{H}, \mathrm{s}, \mathrm{OCH}_{3}\right) ; 3.91\left(3 \mathrm{H}, \mathrm{s}, \mathrm{OCH}_{3}\right) ; 7.02-7.09(4 \mathrm{H}, \mathrm{m}, \mathrm{H}$ ArOMe$) ; 7.78\left(1 \mathrm{H}, \mathrm{dd},{ }^{3} J=8.0,{ }^{3} J=8.0\right.$, H-5 $\mathrm{ArNO}_{2}$ ); 8.00-8.07 (2H, m, H ArOMe); 8.26-8.32 (2H, m, H-4,6 $\left.\operatorname{ArNO}_{2}\right)$; 8.32-8.38 (2H, m, H ArOMe); $8.58\left(1 \mathrm{H}, \mathrm{dd},{ }^{4} J=2.0,{ }^{4} J=2.0, \mathrm{H}-2 \mathrm{ArNO}_{2}\right) ; 8.83(1 \mathrm{H}, \mathrm{s}, \mathrm{CH}=\mathrm{N}) ; 12.27(1 \mathrm{H}$, br. s, NH$) ; 14.58(1 \mathrm{H}$, br. s, NH). ${ }^{13} \mathrm{C}$ NMR spectrum, $\delta$, ppm: 55.5; 55.6; $113.4 ; 114.0 ; 114.1 ; 120.8 ; 123.7 ; 123.8 ; 124.1 ; 129.4 ; 130.0 ; 130.3$; $130.4 ; 132.6 ; 138.1 ; 138.4 ; 141.2 ; 148.1 ; 162.7 ; 162.8$. Mass spectrum, $m / z\left(I_{\text {rel }}, \%\right): 476.15[\mathrm{M}+\mathrm{H}]^{+}(100)$. Found, \%: C 60.39; H 4.27; N 14.71. $\mathrm{C}_{24} \mathrm{H}_{21} \mathrm{~N}_{5} \mathrm{O}_{6}$. Calculated, \%: C 60.63; H 4.45; N 14.73.

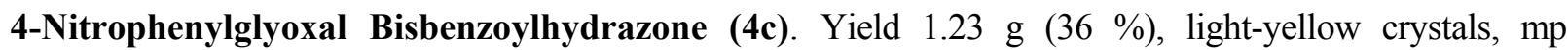
$>250^{\circ} \mathrm{C}$. IR spectrum, $v, \mathrm{~cm}^{-1}: 1659(\mathrm{CO}), 1690(\mathrm{CO}), 3059(\mathrm{NH}), 3213(\mathrm{NH}) .{ }^{1} \mathrm{H}$ NMR spectrum, $\delta, \mathrm{ppm}(J, \mathrm{~Hz})$ : 7.51-7.68 (6H, m, H Ph); 7.93-8.08 (4H, m, H Ph, H ArNO $)$; 8.27-8.32 (2H, m, H Ph); 8.33-8.45 (2H, m, $\left.\mathrm{H} \mathrm{ArNO}_{2}\right) ; 8.82(0.5 \mathrm{H}, \mathrm{s})$ and $8.84(0.5 \mathrm{H}, \mathrm{s}, \mathrm{CH}=\mathrm{N}) ; 12.38(0.5 \mathrm{H}, \mathrm{s}), 12.42(0.5 \mathrm{H}, \mathrm{s}), 14.64(0.5 \mathrm{H}, \mathrm{s})$ and 14.68 $(0.5 \mathrm{H}, \mathrm{s}, 2 \mathrm{NH}) .{ }^{13} \mathrm{C}$ NMR spectrum, $\delta$, ppm: $123.1 ; 125.9 ; 127.4 ; 127.8 ; 128.1 ; 128.4 ; 128.6 ; 128.7 ; 128.9 ; 129.1$; $129.2 ; 132.6 ; 132.7 ; 132.8 ; 132.9 ; 133.0 ; 138.2 ; 140.0 ; 140.4 ; 140.7 ; 142.4 ; 142.6 ; 144.6 ; 148.4 ; 164.3$ (br.). Mass spectrum, $m / z\left(I_{\text {rel }}, \%\right): 416.14[\mathrm{M}+\mathrm{H}]^{+}(100)$. Found, \%: C 63.39; H 3.92; N 16.65. $\mathrm{C}_{22} \mathrm{H}_{17} \mathrm{~N}_{5} \mathrm{O}_{4}$. Calculated, \%: C 63.61; H 4.12; N 16.86.

4-Nitrophenylglyoxal Bis(4-methoxybenzoyl)hydrazone (4d). Yield $1.64 \mathrm{~g}$ (42\%), light-yellow crystals, $\mathrm{mp}>250^{\circ} \mathrm{C}$. IR spectrum, $v, \mathrm{~cm}^{-1}: 1667(\mathrm{CO}), 1701(\mathrm{CO}), 3168(\mathrm{NH}), 3406(\mathrm{NH}) .{ }^{1} \mathrm{H}$ NMR spectrum, $\delta$, ppm $(J, \mathrm{~Hz}): 3.89\left(3 \mathrm{H}, \mathrm{s}, \mathrm{OCH}_{3}\right) ; 3.90\left(3 \mathrm{H}, \mathrm{s}, \mathrm{OCH}_{3}\right) ; 7.01-7.10(4 \mathrm{H}, \mathrm{m}, \mathrm{H} \mathrm{ArOMe}) ; 7.93-8.08$ (4H, m, $\mathrm{H}$ ArOMe, H ArNO $)$; 8.24-8.42 (4H, m, H ArMeO, $\left.\mathrm{H} \mathrm{ArNO}_{2}\right) ; 8.86(1 \mathrm{H}, \mathrm{s}, \mathrm{CH}=\mathrm{N}) ; 12.24(0.5 \mathrm{H}, \mathrm{s}), 12.28$ $(0.5 \mathrm{H}, \mathrm{s}), 14.55(0.5 \mathrm{H}, \mathrm{s})$ and $14.57(0.5 \mathrm{H}, \mathrm{s}, 2 \mathrm{NH}) .{ }^{13} \mathrm{C}$ NMR spectrum, $\delta$, ppm: $56.0 ; 56.1 ; 114.5 ; 114.6$; $115.2 ; 122.9 ; 124.3 ; 124.6 ; 124.8 ; 124.9 ; 125.9 ; 127.2 ; 127.6 ; 128.0 ; 128.3 ; 130.3 ; 130.5 ; 130.7 ; 130.8 ; 138.3$; $139.2 ; 139.6 ; 140.8 ; 141.8 ; 142.0 ; 144.4 ; 148.2 ; 163.2 ; 163.3 ; 163.5$ (br.). Mass spectrum, $m / z\left(I_{\text {rel }}, \%\right): 476.16$ $[\mathrm{M}+\mathrm{H}]^{+}(100)$. Found, \%: C 60.33; H 4.36; N 14.64. $\mathrm{C}_{24} \mathrm{H}_{21} \mathrm{~N}_{5} \mathrm{O}_{6}$. Calculated, \%: C 60.63; H 4.45; N 14.73.

Preparation of Dihydrazones 4e,f (General Method). A mixture of phenacyl bromide 1c,d (5 mmol), 6-methoxycarbonylpyridine-2-carboxylic acid hydrazide (2c) $(1.95 \mathrm{~g}, 10 \mathrm{mmol})$, and NaOAc $(0.49 \mathrm{~g}, 6 \mathrm{mmol})$ in a mixture of EtOH-AcOH, 1:3 $(100 \mathrm{ml})$ was refluxed for $12 \mathrm{~h}$. The solvent was distilled off at reduced pressure, and the residue treated with EtOH. The precipitated solid was filtered off, washed with EtOH, and dried. Analytical samples of compounds $4 \mathbf{e}, \mathbf{f}$ were obtained by recrystallization from MeCN.

Phenylglyoxal Bis[(6-methoxycarbonylpyridin-2-yl)carbonyl]hydrazone (4e). Yield $0.73 \mathrm{~g} \mathrm{(30 \% ),}$

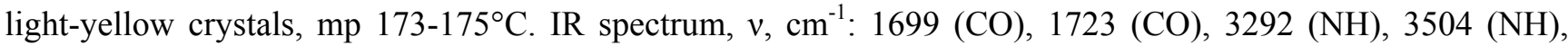
$3593(\mathrm{NH}) .{ }^{1} \mathrm{H}$ NMR spectrum, $\delta$, ppm $(J, \mathrm{~Hz}): 3.82\left(3 \mathrm{H}, \mathrm{s}, \mathrm{COOCH}_{3}\right) ; 3.97\left(3 \mathrm{H}, \mathrm{s}, \mathrm{COOCH}_{3}\right) ; 7.45-7.49(2 \mathrm{H}$, m, H Ph); 7.66-7.80 (3H, m, H Ph); 8.20-8.35 (6H, m, H Py); $8.68(1 \mathrm{H}, \mathrm{s}, \mathrm{CH}=\mathrm{N}) ; 11.26(1 \mathrm{H}, \mathrm{s}, \mathrm{NH}) ; 12.22$ $(1 \mathrm{H}, \mathrm{s}, \mathrm{NH}) .{ }^{13} \mathrm{C}$ NMR spectrum, $\delta$, ppm: $53.1 ; 53.2 ; 126.1 ; 126.7 ; 128.1 ; 128.4 ; 129.0 ; 129.4 ; 129.8 ; 130.4$; $140.0 ; 140.6 ; 146.6 ; 147.4 ; 148.6 ; 150.2 ; 150.6 ; 154.3 ; 158.7 ; 161.0 ; 164.5 ; 165.2$. Mass spectrum, $m / z\left(I_{\text {rel }}, \%\right)$ : $489.15[\mathrm{M}+\mathrm{H}]^{+}$(100). Found, \%: C 58.88; H 3.96; N 16.94. $\mathrm{C}_{24} \mathrm{H}_{20} \mathrm{~N}_{6} \mathrm{O}_{6}$. Calculated, \%: C 59.02; $\mathrm{H}$ 4.13; $\mathrm{N} 17.21$.

4-Methoxyphenylglyoxal Bis[(6-methoxycarbonylpyridin-2-yl)carbonyl]hydrazone (4e). Yield $0.74 \mathrm{~g}$ (29\%), light-yellow crystals, mp $181-183^{\circ} \mathrm{C} .{ }^{1} \mathrm{H}$ NMR spectrum, $\delta, \mathrm{ppm}(\mathrm{J}, \mathrm{Hz}): 3.81\left(3 \mathrm{H}, \mathrm{s}, \mathrm{COOCH}_{3}\right) ; 3.93(3 \mathrm{H}$, $\left.\mathrm{s}, \mathrm{ArOCH}_{3}\right) ; 3.97\left(3 \mathrm{H}, \mathrm{s}, \mathrm{COOCH}_{3}\right) ; 7.21-7.26(2 \mathrm{H}, \mathrm{m}, \mathrm{H} \mathrm{Ar}) ; 7.43-7.47(2 \mathrm{H}, \mathrm{m}, \mathrm{H} \mathrm{Ar}) ; 8.20-8.37(6 \mathrm{H}, \mathrm{m}$, 
H Py); $8.65(1 \mathrm{H}, \mathrm{s}, \mathrm{CH}=\mathrm{N}) ; 11.33(1 \mathrm{H}, \mathrm{s}, \mathrm{NH}) ; 12.27(1 \mathrm{H}, \mathrm{s}, \mathrm{NH})$. Mass spectrum, $m / z\left(I_{\text {rel }}, \%\right): 519.16$ $[\mathrm{M}+\mathrm{H}]^{+}(100)$. Found, \%: C 57.69; H 4.17; N 16.01. $\mathrm{C}_{25} \mathrm{H}_{22} \mathrm{~N}_{6} \mathrm{O}_{7}$. Calculated, \%: C 57.91; H 4.28; N 16.21.

The work was carried out with the support of the Ministry of Education and Science of the Russian Federation (State contracts \# 14.740.11.1020 and 14.A18.21.0817), the Russian Foundation for Basic Research (grant 12-03-31726) and the Grants Council of the President of the Russian Federation (grant MK1511.2013.3).

\section{REFERENCES}

1. G. R. Pabst, O. C. Pfüller, and J. Sauer, Tetrahedron, 55, 8045 (1999).

2. A. Rykowski, D. Branowska, and J. Kielak, Tetrahedron Lett., 41, 3657 (2000).

3. D. N. Kozhevnikov, V. N. Kozhevnikov, M. M. Ustinova, A. Santoro, D. W. Bruce, B. Koenig, R. Czerwieniec, T. Fischer, M. Zabel, and H. Yersin, Inorg. Chem., 4179 (2009).

4. R. M. Abdel-Rahman, Pharmazie, 56, 195 (2001).

5. A. M. El Massry, A. M. Asal, S. N. Khattab, N. S. Haiba, H. A. Awney, M. Helmy, V. Langer, and A. Amer, Bioorg. Med. Chem., 20, 2624 (2012).

6. E. F. Mesaros, T. V. Thieu, G. J. Wells, C. A. Zificsak, J. C. Wagner, H. J. Breslin, R. Tripathy, J. L. Diebold, R. J. McHugh, A. T. Wohler, M. R. Quail, W. Wan, L. Lu, Z. Huang, M. S. Albom, T. S. Angeles, K. J. Wells-Knecht, L. D. Aimone, M. Cheng, M. A. Ator, G. R. Ott, and B. D. Dorsey, J. Med. Chem., 55, 115 (2012).

7. Z. Kolarik, U. Mullich, and F. Gassner, Solvent Extr. Ion Exch., 17, 23 (1999).

8. Z. Kolarik, U. Mullich, and F. Gassner, Solvent Extr. Ion Exch., 17, 1155 (1999).

9. $\quad$ F. W. Lewis, M. J. Hudson, and L. M. Harwood, Synlett, 2609 (2011).

10. A. Zhang, Y. Zhu, and Z. Chai, J. Chem. Eng. Data, 57, 1267 (2012).

11. A. M. Prokhorov, D. N. Kozhevnikov, V. L. Rusinov, A. I. Matern, M. M. Nikitin, O. N. Chupakhin, I. L. Eremenko, and G. G. Aleksandrov, Zh. Org. Khim., 41, 1736 (2005). [Rus. J. Org. Chem., 41, 1702 (2005).]

12. T. V. Saraswathi and V. R. Srinivasan, Tetrahedron Lett., 12, 2315 (1971).

13. A. M. Prokhorov, V. N. Kozhevnikov, D. S. Kopchuk, H. Bernard, N. Le Bris, R. Tripier, H. Handel, B. Koenig, and D. N. Kozhevnikov, Tetrahedron, 67, 597 (2011).

14. N. I. Korotkikh, A. Yu. Chervinskii, S. N. Baranov, L. M. Kapkan, and O. P. Shvaika, Zh. Org. Khim., 15, 962 (1979). 